\title{
Inheritance of Cross-sensitivity in Sweet Corn to Herbicides Applied Postemergence
}

\author{
Jerald K. Pataky ${ }^{1}$ and Jonathan N. Nordby \\ Department of Crop Sciences, University of Illinois, Urbana, IL 61801 \\ Martin M. Williams II \\ United States Department of Agriculture-Agricultural Research Service, Invasive Weed Management \\ Research, University of Illinois, Urbana, IL 61801
}

Dean E. Riechers
Department of Crop Sciences, University of Illinois, Urbana, IL 61801

AdDitional INDEX words. bentazon, carfentrazone, dicamba + diflufenzopyr, foramsulfuron, mesotrione, nicosulfuron, primisulfuron, rimsulfuron, cytochrome $\mathrm{P} 450$, herbicide selectivity, herbicide tolerance, Zea mays

\begin{abstract}
Aвstract. Some sweet corn (Zea mays L.) hybrids and inbreds can be severely injured by applications of postemergence herbicides. An association was observed between the responses of sweet corn hybrids and inbreds to nicosulfuron and mesotrione, and $\mathrm{F}_{2}$ families derived from a cross of a sensitive $(\mathrm{Cr} 1)$ and a tolerant $(\mathrm{Cr} 2)$ sweet corn inbred segregated for response to these two herbicides. These observations prompted us to examine the inheritance of sensitivity in sweet corn to multiple postemergence herbicide treatments with different modes of action and to determine if there was a common genetic basis for cross-sensitivity to these herbicides. The sensitive and tolerant inbreds, progeny in the $\mathbf{F}_{1}$, $\mathrm{F}_{2}, \mathrm{BC}_{1}$, and $\mathrm{BC}_{2}$ generations, and $\mathrm{BC}_{1} \mathrm{~S}_{1}, \mathrm{BC}_{2} \mathrm{~S}_{1}, \mathrm{~F}_{2: 3}\left(\mathrm{~S}_{1: 2}\right)$ and $\mathrm{F}_{3: 4}\left(\mathrm{~S}_{2: 3}\right)$ families were screened for responses to eight herbicide treatments. Based on segregation of tolerant and sensitive progeny and segregation of family responses, our data indicate that a single recessive gene in $\mathrm{Cr} 1$ conditioned sensitivity to four acetolactate synthase (ALS)-inhibiting herbicides (foramsulfuron, nicosulfuron, primisulfuron, and rimsulfuron), a 4-hydroxyphenylpyruvate dioxygenase (HPPD)-inhibiting herbicide (mesotrione), a growth regulator herbicide combination (dicamba + diflufenzopyr), and a protoporphyrinogen oxidase (PPO)-inhibiting herbicide (carfentrazone). Based on highly significant positive correlations of phenotypic responses among $\mathrm{BC}_{1} \mathrm{~S}_{1}, \mathrm{BC}_{2} \mathrm{~S}_{1}, \mathrm{~F}_{2: 3}$, and $\mathrm{F}_{3: 4}$ families, the same gene (or closely linked genes) appeared to condition responses to each of these herbicide treatments. The dominant allele also conditions tolerance to bentazon [a photosystem II (PSII)-inhibiting herbicide] although another gene(s) also appeared to affect bentazon tolerance.
\end{abstract}

The potential for crop injury limits the use of postemergence herbicides in sweet corn. Under certain environmental conditions, some hybrids and inbreds can be severely injured by postemergence applications of several herbicides, including nicosulfuron (Burton et al., 1994; Grey et al., 2000; Monks et al., 1992; Morton and Harvey, 1992; O'Sullivan and Bouw, 1998; O'Sullivan et al., 1995, 2000; Robinson et al., 1993, 1994; Stall and Bewick, 1992; Williams et al., 2005), mesotrione (Masiunas et al., 2004; O'Sullivan et al., 2002; Williams et al., 2005), bentazon (Diebold et al., 2004), primisulfuron (Burton et al., 1994; Grey et al., 2000; Monks et al., 1992; O'Sullivan and Sikkema, 2002), rimsulfuron (O'Sullivan and Bouw, 1998; O'Sullivan et al., 1995), and foramsulfuron (Diebold et al., 2003). Consequently, evaluations of new sweet corn hybrids and inbreds for sensitivity to herbicides and evaluations of new herbicides for potential injury on widely used sweet corn germplasm have become routine.

During a recent screening program, an association was observed between the responses of sweet corn hybrids to nicosulfuron and mesotrione(Williams et al., 2005). Nicosulfuron-sensitive hybrids

Received for publication 13 Mar. 2006. Accepted for publication 17 June 2006 The authors greatly appreciate the cooperation of Crookham Company, Caldwell, Idaho. A portion of this research was supported by funding from the Midwest Food Processors Association. Mention of a trademark, proprietary product, or vendor does not constitute a guarantee or warranty of the product by the U.S. Dept. of Agriculture and does not imply its approval to the exclusion of other products or vendors that also may be suitable.

'Corresponding author; e-mail: j-pataky@uiuc.edu were more likely to be sensitive to mesotrione than nicosulfuron-tolerant hybrids and vice versa. This association was more evident among inbreds and $\mathrm{F}_{2}$ families derived from a cross of a sensitive inbred, $\mathrm{Cr} 1$, and a tolerant inbred, $\mathrm{Cr} 2$. A similar but less explicit association also was observed among responses of inbreds and $\mathrm{F}_{2}$ families to dicamba + diflufenzopyr and carfentrazone (M.M. Williams, J.K. Pataky, J.N. Nordby, D.E. Riechers, C.L. Sprague, and J.B. Masiunas, unpublished). Segregation of $\mathrm{F}_{2}$ families for response to nicosulfuron and mesotrione fit a 1:2:1 pattern that would be expected if sensitivity was conditioned by a single recessive gene. The strong association between responses of inbreds and $\mathrm{F}_{2}$ families to nicosulfuron and mesotrione, and possibly to dicamba + diflufenzopyr and carfentrazone, suggested that the same gene may condition response to multiple herbicide treatments. However, sample size of $\mathrm{F}_{3}$ plants in $\mathrm{F}_{2}$ families was small. Additional experiments with larger sample sizes were deemed necessary to confirm these preliminary observations (Williams et al., 2005).

Differences in rates of metabolic inactivation are the primary basis for differential sensitivity in corn and other plants to sulfonylurea herbicides such as nicosulfuron (Barrett, 1995; Burton et al., 1994; Fonné-Pfister et al., 1990; Green, 1998; Green and Ulrich, 1993; Harms et al., 1990; Hinz and Owen, 1996). Nicosulfuron is hydroxylated by cytochrome P450 enzymes in corn as a Phase I detoxification reaction (Kreuz et al., 1996). Cytochrome P450 activity in corn also metabolizes herbicides in at least five other chemical families; however, the number of P450s involved and regulation of their levels of activity are not clearly understood 
(Barrett, 1995, 2000; Boldtetal., 1992). Corn has many cytochrome P450 genes (Frey et al., 1995). Interestingly, a few or possibly even one P450 in corn are primarily responsible for herbicide metabolism (Barrett, 1995; Barrett et al., 1994). A field corn inbred, GA209, originally identified as bentazon-sensitive, was more sensitive to imazethapyr, nicosulfuron, primisulfuron, and chlortoluron and slightly more sensitive to dicamba than B73, a bentazon-tolerant inbred (Barrett et al., 1997). Within a 24-h period after excised shoots of GA209 and B73 were treated with radiolabeled bentazon, imazethapyr, and nicosulfuron, $75 \%$ or more of the amount of each herbicide absorbed was metabolized by B73 but $<25 \%$ was metabolized by GA209 (Barrett et al., 1997).

The genetic basis for herbicide sensitivity in corn has been examined for several herbicides. Based on responses of progeny from crosses of a bentazon-sensitive field corn inbred, GA209, and bentazon-tolerant corn lines, Fleming et al. (1988) proposed that tolerance to bentazon was conditioned by a single gene designated as Ben. Subsequently, Bradshaw et al. (1994) reported that sensitivity of GA209 to bentazon was controlled by a single recessive gene or possibly by two recessive genes designated as benl and ben2. Co-dominance was proposed for sensitivity to chlorsulfuron based on intermediate responses of crosses of tolerant (T) and sensitive ( $\mathrm{S}$ ) corn lines compared to tolerant responses of $\mathrm{T} \times \mathrm{T}$ crosses and sensitive responses of $\mathrm{S} \times \mathrm{S}$ crosses (Landi et al., 1989). Tolerance to primisulfuron was conditioned by a single dominant gene when a tolerant field corn inbred, 4C0, was crossed with a sensitive inbred, 4N5 (Harms et al., 1990). Green and Ulrich (1993) reported that sensitivity of field corn and sweet corn to three sulfonylurea herbicides (nicosulfuron, primisulfuron, and thifensulfuron) was conditioned by a single recessive gene. Sensitivity to nicosulfuron in the field corn inbreds Mp313E and L688 was inherited as a single recessive gene, which was designated as nsfl (Kang, 1993). Sensitivity of the field corn inbred Ab18 to nicosulfuron also was conditioned by a single recessive gene (Widstrom and Dowler, 1995). Moreno et al. (1999) used maize B-A translocation stocks to map the $n s f l$ gene to the short arm of chromosome 7. Green (1998) cited an unpublished report that mapped sensitivity to rimsulfuron in the field corn inbred $\mathrm{F}_{2}$ to the short arm of chromosome 5. Williams et al. (2006) used a map-based cloning approach to establish the location and sequence of the $n s f l$ gene on the short arm of chromosome 5 .
A better understanding of the phenotypic and genetic relationships between responses of sweet corn to various herbicides will help sweet corn breeders identify and eliminate sensitive germplasm in breeding programs and will allow herbicide manufacturers to construct pesticide labels that adequately address the risks of using herbicides on sweet corn. The objectives of this study were to examine the inheritance of sensitivity in sweet corn to eight postemergence herbicide treatments (bentazon, carfentrazone, dicamba + diflufenzopyr, foramsulfuron, mesotrione, nicosulfuron, primisulfuron, and rimsulfuron) having five different modes of action (PSII-inhibiting, PPO-inhibiting, growth regulator, ALS-inhibiting, and HPPD-inhibiting), and to determine if there is a common genetic basis resulting in crosssensitivity to these herbicides.

\section{Materials and Methods}

Plant material. Sweet corn inbreds $\mathrm{Cr} 1$ and $\mathrm{Cr} 2$ (Crookham Co., Caldwell, Idaho) were identified as sensitive and tolerant, respectively, to nicosulfuron and mesotrione in previous trials (Williams et al., 2005). The $\mathrm{F}_{1}, \mathrm{~F}_{2}, \mathrm{BC}_{1}$, and $\mathrm{BC}_{2}$ generations were produced by crossing $\mathrm{Cr} 1$ and $\mathrm{Cr} 2$ and self-pollinating or backcrossing. These generations were evaluated for responses to four or eight different herbicide treatments in greenhouse or field trials, respectively. Reciprocal $\mathrm{F}_{1}$ and backcross generations were included in each trial. $\mathrm{BC}_{1} \mathrm{~S}_{1}, \mathrm{BC}_{2} \mathrm{~S}_{1}$, and $\mathrm{F}_{3}\left(\mathrm{~S}_{2}\right.$ plants $)$ generations were produced by self-pollinating $\mathrm{BC}_{1}, \mathrm{BC}_{2}$, and $\mathrm{F}_{2}$ plants earto-row for an additional generation. These generations also were evaluated in field trials for responses to five herbicide treatments. $\mathrm{F}_{3: 4}$ families that were developed by self-pollinating $\mathrm{F}_{1}$ plants ear-to-row for three generations were evaluated for responses to four herbicide treatments in greenhouse trials.

Herbicide treatments evaluated. Commercial formulation of herbicide treatments was applied with adjuvants (Table 1). Herbicide treatments evaluated in greenhouse trials included an ALS-inhibitor (nicosulfuron), an HPPD-inhibitor (mesotrione), a growth regulator (dicamba + diflufenzopyr), and a PPO-inhibitor (carfentrazone). These four herbicide treatments also were evaluated in the field trials along with three additional ALS-inhibitors (foramsulfuron, primisulfuron, and rimsulfuron) and a PSII-inhibitor (bentazon).

Table 1. Sweet corn inbreds $\mathrm{Cr} 1$ and $\mathrm{Cr} 2$ and progeny from the $\mathrm{F}_{1}$ cross of these inbreds evaluated for responses to the following herbicide treatments in greenhouse and field trials.

\begin{tabular}{llcl}
\hline \multirow{2}{*}{ Trial } & \multicolumn{1}{c}{ Herbicide } & $\begin{array}{c}\text { Rate of application } \\
\left(\mathrm{g} \cdot \mathrm{ha}^{-1} \text { a.i. }\right.\end{array}$ & \multicolumn{1}{c}{ Adjuvants $^{z}$} \\
\hline Greenhouse & Nicosulfuron & 35 & $0.25 \%$ NIS and $2.5 \%$ UAN \\
& Mesotrione & 105 & $1 \%$ COC \\
& Dicamba+diflufenzopyr & $210+85$ & $0.25 \%$ NIS and $2.5 \%$ UAN \\
& Carfentrazone & 19 & $1 \%$ COC \\
Field & Nicosulfuron & 35 & $1 \%$ COC and $2.5 \%$ UAN \\
& Mesotrione & 105 & $1 \%$ COC and $2.5 \%$ UAN \\
& Dicamba+diflufenzopyr & $210+85$ & $0.25 \%$ NIS and $1.25 \%$ UAN \\
& Carfentrazone & 19 & $1 \%$ COC \\
& Foramsulfuron & 37 & $1.35 \%$ MSO and $3.6 \%$ UAN \\
& Bentazon & 1120 & $0.9 \%$ COC and $3.6 \%$ UAN \\
& Primisulfuron & 40 & $1 \%$ COC and $7.2 \%$ UAN \\
& Rimsulfuron & 19 & $1 \%$ MSO \\
\hline
\end{tabular}

${ }^{\mathrm{z}}$ All adjuvants applied as a percent total spray volume; $\mathrm{NIS}=$ nonionic surfactant; $\mathrm{UAN}=28 \%$ urea ammonium nitrate; $\mathrm{COC}=$ crop oil concentrate; $\mathrm{MSO}=$ methylated seed oil. 
Greenhouse trials. Both parental inbreds and $\mathrm{F}_{1}, \mathrm{~F}_{2}, \mathrm{BC}_{1}$, and $\mathrm{BC}_{2}$ generations were evaluated for responses to nicosulfuron, mesotrione, dicamba + diflufenzopyr, and carfentrazone in greenhouse trials at the University of Illinois Plant Care Facility, Urbana. Each trial included three replicates of $\mathrm{Cr} 1, \mathrm{Cr} 2, \mathrm{~F}_{1}$, and $\mathrm{BC}_{2}$ generations, five replicates of the $\mathrm{F}_{2}$ generation, and 10 replicates of the $\mathrm{BC}_{1}$ generation. Sixty plants were grown per 30 $\times 60 \times 7$-cm flat filled with 1:1:1 mixture of soil, peat, and perlite supplemented with 14N-6.1P-11.6K Osmocote (The Scotts Co., Marysville, Ohio) pellets. An experimental unit was three rows in one-half of a flat with 10 seeds planted per row. Two generations were planted per flat. Generations were arranged in a completely random design. Air temperature was maintained at $24 \pm 4{ }^{\circ} \mathrm{C}$ during a 14 -h day. Sunlight was supplemented with metal halide lamps for an intensity of $1000 \mu \mathrm{mol} \cdot \mathrm{m}^{-2} \cdot \mathrm{s}^{-1}$ at the plant surface for $14 \mathrm{~h}$.

$\mathrm{F}_{4}$ plants in $143 \mathrm{~F}_{3}$ families also were evaluated for responses to nicosulfuron, mesotrione, dicamba+diflufenzopyr, and carfentrazone in greenhouse trials. An experimental unit was approximately 30 plants per family in three rows of one-half of a flat. Two families were planted per flat. Families were arranged randomly within trials. Each flat also included two plants each of $\mathrm{Cr} 1$ and $\mathrm{Cr} 2$ as controls; and each trial also included at least two experimental units each of $\mathrm{Cr} 1, \mathrm{Cr} 2$, and $\mathrm{Cr} 1 \times \mathrm{Cr} 2$ as controls.

Commercial formulations of herbicide treatments were applied when plants were at the three- to four-leaf stage (Ritchie et al., 2003). Two flats of plants were treated simultaneously in an herbicide spray chamber equipped with an $80^{\circ}$ flat-fan nozzle delivering $187 \mathrm{~L} \cdot \mathrm{ha}^{-1}$ of treatment solutions at $207 \mathrm{kPa}$ (Table 1).

Seven to 10 days after herbicide treatments were applied, each plant was rated visually as sensitive or tolerant based on symptoms of injury due to nicosulfuron, mesotrione, or dicamba+diflufenzopyr. Plants sensitive to nicosulfuron were mostly necrotic. Leaves of plants sensitive to mesotrione were bleached and severely chlorotic. Plants sensitive to dicamba + diflufenzopyr grew abnormally with rolled leaves and calloused tissue at the soil line that caused seedlings to lodge severely. For carfentrazone (a contact herbicide), all plants were injured to some degree. Severity of shoot necrosis was rated visually for each plant from 1 (no injury) to 9 (100\% leaf area necrotic) except for $\mathrm{F}_{4}$ plants in the $\mathrm{F}_{3}$ family study, in which case each experimental unit was assigned two ratings independently by each of two investigators. The four ratings were then averaged for each experimental unit. Families in the $\mathrm{F}_{3: 4}$ study were classified as sensitive, segregating, or tolerant to nicosulfuron, mesotrione, and dicamba + diflufenzopyr based on the percentage of injured $\mathrm{F}_{4}$ plants per family which would be expected to be $100 \%, 25 \%$ and $0 \%$ for sensitive, segregating, and tolerant families, respectively, if tolerance was conditioned by a single gene. Families were classified as sensitive if the number of sensitive plants was greater than expected for segregating families for a single gene based on chi-square goodness-of-fit tests with $P$ $<0.002$ (about $50 \%$ or more of the plants were injured). Families were classified as tolerant if the number of sensitive plants was less than expected for segregating families based on chi-square goodness-of-fit tests with $P<0.06$ (less than $\sim 12 \%$ of the plants were injured). If $12 \%$ to $49 \%$ of the plants were injured, families were classified as segregating. Families were classified as sensitive to carfentrazone if the average rating was 6.6 or higher, segregating if the average rating was between 5.4 and 6.5, and tolerant if the average rating was 5.3 or less.

For nicosulfuron, mesotrione, and dicamba+diflufenzopyr, ratios of tolerant and sensitive plants in the $\mathrm{F}_{2}$ and $\mathrm{BC}_{1}$ generations were compared by chi-square goodness-of-fit tests to $3: 1$ and $1: 1$, respectively, which would be expected if herbicide tolerance was conditioned by a single, dominant gene. Generation mean values were compared for injury ratings for carfentrazone. The ratio of sensitive, segregating, and tolerant $\mathrm{F}_{3}$ families also was compared for each herbicide treatment by a chi-square goodness-of-fit test to a $3: 2: 3$ ratio that would be expected if a single gene conditioned response to each herbicide treatment. Correlation coefficients were calculated among responses of the $\mathrm{F}_{3}$ families to the four herbicide treatments using PROC CORR of SAS (SAS Institute Inc., Cary, N.C.). The dependent variables were the percentage of plants per $\mathrm{F}_{3}$ family injured by nicosulfuron, mesotrione, or dicamba + diflufenzopyr, and the family mean injury rating for carfentrazone.

FiELd TRIALS. Two sets of field trials were planted 5 May 2005 at the University of Illinois Crop Sciences Research and Education Center, Urbana. One set of field trials included two replicates of both parental inbreds and $\mathrm{F}_{1}, \mathrm{~F}_{2}, \mathrm{BC}_{1}, \mathrm{BC}_{2}, \mathrm{BC}_{1} \mathrm{~S}_{1}$, $\mathrm{BC}_{2} \mathrm{~S}_{1}$, and $\mathrm{F}_{3}$ generations evaluated for responses to nicosulfuron, mesotrione, dicamba + diflufenzopyr, carfentrazone, foramsulfuron, and bentazon. Each herbicide treatment was a separate trial. The number of rows per experimental unit differed among generations. In all trials, each replicate included one row each of $\mathrm{Cr} 1, \mathrm{Cr} 2$, and the $\mathrm{F}_{1}$, three rows each of the $\mathrm{BC}_{1}, \mathrm{BC}_{2}$ and $\mathrm{F}_{2}$ generations, and one row each of $28 \mathrm{BC}_{1} \mathrm{~S}_{1}$ families, $28 \mathrm{BC}_{2} \mathrm{~S}_{1}$ families, and $30 \mathrm{~F}_{2}$ families. Rows were $5.3 \mathrm{~m}$ long with 26 seed planted per row.

In a second set of field trials, four replicates of both parental inbreds and $\mathrm{F}_{1}, \mathrm{~F}_{2}, \mathrm{BC}_{1}$, and $\mathrm{BC}_{2}$ generations were evaluated for responses to primisulfuron and rimsulfuron. The two herbicides were separate trials. In both trials, each replicate included one row each of $\mathrm{Cr} 1, \mathrm{Cr} 2$, and $\mathrm{F}_{1}$; two rows of the $\mathrm{BC}_{2}$ generation, four rows of the $\mathrm{BC}_{1}$ generation and five rows of the $\mathrm{F}_{2}$ generation. Rows were $5.3 \mathrm{~m}$ long with 26 seed planted per row.

Commercial formulations of herbicides were applied at rates indicated in Table 1 when plants were at the four- to six-leaf stage (Ritchie et al., 2003). All herbicides were applied on the same day using a tractor-mounted compressed-air sprayer calibrated to deliver $148 \mathrm{~L} \cdot \mathrm{ha}^{-1}$ of spray solution at $209 \mathrm{kPa}$.

In all trials except those treated with carfentrazone, each plant was rated visually as tolerant or sensitive 7 and $21 \mathrm{~d}$ after application of herbicide treatments. In the carfentrazone trial, all plants had some degree of shoot necrosis. Therefore, two investigators independently rated symptoms of carfentrazone injury for each experimental unit $14 \mathrm{~d}$ after treatment using a scale from 1 (no injury) to 9 (100\% leaf area necrotic). Carfentrazone injury ratings were averaged over investigators and replicates.

Ratios of plants sensitive or tolerant to five herbicide treatments (nicosulfuron, mesotrione, dicamba + diflufenzopyr, foramsulfuron, and bentazon) in the $\mathrm{F}_{2}, \mathrm{BC}_{1}, \mathrm{~F}_{3}, \mathrm{BC}_{1} \mathrm{~S}_{1}$, and $\mathrm{BC}_{2} \mathrm{~S}_{1}$ generations were compared by chi-square goodness-offit tests to ratios that would be expected if herbicide tolerance was conditioned by a single, dominant gene. Generation means were compared for injury ratings for carfentrazone. The ratios of sensitive, segregating, and tolerant $\mathrm{BC}_{1} \mathrm{~S}_{1}, \mathrm{BC}_{2} \mathrm{~S}_{1}$, and $\mathrm{F}_{2}$ families for each of the six herbicides also were compared by chi-square goodness-of-fit tests to ratios that would be expected if a single, dominant gene conditioned response to the herbicides. Families were considered to be sensitive if more than $60 \%$ of the plants were injured, segregating if $9 \%$ to $60 \%$ of the plants were injured, and tolerant if less than $9 \%$ of the plants were injured. Families 
Table 2. Segregation analysis for responses to nicosulfuron, mesotrione, and dicamba + diflufenzopyr and carfentrazone injury rating when sweet corn inbreds $\mathrm{Cr} 1$ and $\mathrm{Cr} 2$ and their progeny were screened in greenhouse trials.

\begin{tabular}{|c|c|c|c|c|c|c|c|c|c|c|c|c|c|c|c|}
\hline \multirow[b]{3}{*}{ Generation } & \multicolumn{14}{|c|}{$\begin{array}{l}\text { Segregation for tolerant }(\mathrm{T}) \text { and sensitive }(\mathrm{S}) \text { plants } \\
\text { following herbicide treatments (no. progeny) }\end{array}$} & \multirow{3}{*}{$\begin{array}{c}\text { Carfentrazone } \\
\text { injury } \\
(1-9)\end{array}$} \\
\hline & \multicolumn{2}{|c|}{ Expected ratios ${ }^{\mathrm{z}}$} & \multicolumn{4}{|c|}{ Nicosulfuron } & \multicolumn{4}{|c|}{ Mesotrione } & \multicolumn{4}{|c|}{ Dicamba + diflufenzopyr } & \\
\hline & $\mathrm{T}$ & $\mathrm{S}$ & $\mathrm{T}$ & $\mathrm{S}$ & $\chi^{2}$ & $P$ & $\mathrm{~T}$ & $\mathrm{~S}$ & $\chi^{2}$ & $P$ & $\mathrm{~T}$ & $\mathrm{~S}$ & $\chi^{2}$ & $P$ & \\
\hline$\overline{\mathrm{Cr} 1}$ & 0 & 1 & 0 & 74 & & & 0 & 75 & & & 0 & 47 & & & 7 \\
\hline $\mathrm{Cr} 2$ & 1 & 0 & 63 & 0 & & & 54 & 0 & & & 49 & 0 & & & 5.3 \\
\hline $\mathrm{F}_{1}$ & 1 & 0 & 64 & 0 & & & 52 & 6 & & & 44 & 8 & & & 5.8 \\
\hline $\mathrm{F}_{2}$ & 3 & 1 & 102 & 28 & 0.83 & 0.36 & 113 & 30 & 1.23 & 0.27 & 107 & 33 & 0.15 & 0.70 & 5.9 \\
\hline $\mathrm{BC}_{1}$ & 1 & 1 & 113 & 102 & 0.56 & 0.45 & 100 & 117 & 1.33 & 0.25 & 115 & 123 & 0.27 & 0.60 & 6.1 \\
\hline $\mathrm{BC}_{2}$ & 1 & 0 & 53 & 0 & & & 78 & 0 & & & 61 & 2 & & & 5.2 \\
\hline
\end{tabular}

${ }^{2}$ Expected ratios of tolerant and sensitive plants if tolerance is conditioned by a single, dominant gene.

were classified as sensitive to carfentrazone if the average rating was 6.5 or higher, segregating if the average rating was between 4.5 and 6.5 , and tolerant if the average rating was 4.5 or less.

Correlation coefficients were calculated among responses of the $28 \mathrm{BC}_{1} \mathrm{~S}_{1}, 28 \mathrm{BC}_{2} \mathrm{~S}_{1}$, and $30 \mathrm{~F}_{2}$ families to the six herbicide treatments using PROC CORR of SAS. The dependent variables were the percentage of plants per family injured by nicosulfuron, mesotrione, dicamba + diflufenzopyr, foramsulfuron, and bentazon, and the family mean injury rating for carfentrazone.

In the second set of field trials, ratios of plants tolerant or sensitive to primisulfuron and rimsulfuron in the $\mathrm{F}_{2}$ and $\mathrm{BC}_{1}$ generations were compared by chi-square goodness-of-fit tests to $3: 1$ and 1:1 ratios, respectively, which would be expected if herbicide tolerance was conditioned by a single, dominant gene.

\section{Results}

Greenhouse TRIaLs. Segregation of progeny in the $\mathrm{F}_{2}$ and $\mathrm{BC}_{1}$ generations and segregation of $\mathrm{F}_{3: 4}$ family responses to nicosulfuron, mesotrione, dicamba + diflufenzopyr, and carfentrazone were not different from the ratios expected if tolerance was conditioned by a single, dominant gene. All plants of $\mathrm{Cr} 1$ were sensitive to nicosulfuron, mesotrione, and dicamba+diflufenzopyr; and the carfentrazone injury rating was 7 (Table 2). All plants of $\mathrm{Cr} 2$ and all progeny in the $\mathrm{F}_{1}$ and $\mathrm{BC}_{2}$ generations were tolerant to nicosulfuron, mesotrione, and dicamba + diflufenzopyr, although some plants in the $\mathrm{F}_{1}$ and $\mathrm{BC}_{2}$ generations had very mild symptoms of injury from mesotrione and dicamba + diflufenzopyr that we classified as tolerant. Carfentrazone injury ratings were 5.3, 5.8, and 5.2 for $\mathrm{Cr} 2$, the $\mathrm{F}_{1}$ and $\mathrm{BC}_{2}$ generations, respectively. Based on chi-square goodness-of-fit tests, ratios of tolerant and sensitive progeny in the $\mathrm{F}_{2}$ and $\mathrm{BC}_{1}$ generations were not significantly different $(P>0.01)$ from 3:1 and 1:1, respectively. There were no differences between reciprocal $\mathrm{BC}_{1}$ generations. Carfentrazone injury ratings were 5.9 and 6.1 for the $\mathrm{F}_{2}$ and $\mathrm{BC}_{1}$ generations, respectively.

Ratios of tolerant, segregating, and sensitive responses of $\mathrm{F}_{3: 4}$ families to nicosulfuron, mesotrione, dicamba + diflufenzopyr, and carfentrazone were not significantly different $(P>0.01)$ from $3: 2: 3$, although the probability associated with the chisquare goodness-of-fit test was 0.03 for responses of $\mathrm{F}_{3: 4}$ families to carfentrazone (Table 3 ). Correlations among the percentage of $\mathrm{F}_{4}$ plants in $\mathrm{F}_{3}$ families that were sensitive to nicosulfuron, mesotrione, dicamba + diflufenzopyr, and carfentrazone injury ratings for $\mathrm{F}_{3: 4}$ families ranged from 0.93 for nicosulfuron and mesotrione to 0.73 for dicamba + diflufenzopyr and carfentrazone (Table 4).
Table 3. Segregation analysis for response to nicosulfuron, mesotrione, dicamba + diflufenzopyr, and carfentrazone when $\mathrm{F}_{3: 4}$ families derived from crosses of sweet corn inbreds $\mathrm{Cr} 1$ and $\mathrm{Cr} 2$ were screened in greenhouse trials.

\begin{tabular}{lccccc}
\hline & \multicolumn{5}{c}{ Segregation ${ }^{\mathrm{z}}$ of $\mathrm{F}_{3: 4}$ families (no. families) } \\
\cline { 2 - 6 } Herbicide treatment & $\mathrm{T}$ & Seg. & $\mathrm{S}$ & $\chi^{2}$ & $P$ \\
\hline Nicosulfuron & 44 & 45 & 52 & 4.2 & 0.12 \\
Mesotrione & 47 & 48 & 48 & 5.6 & 0.06 \\
Dicamba + diflufenzopyr & 49 & 41 & 50 & 1.4 & 0.50 \\
Carfentrazone & 44 & 48 & 47 & 6.8 & 0.03
\end{tabular}

${ }^{2}$ Expected ratio of tolerant, segregating, and sensitive $F_{3: 4}$ families is $3: 2: 3$ if tolerance is conditioned by a single, dominant gene.

$\mathrm{y} \mathrm{T}=$ tolerant response to herbicide; Seg. = segregating response to herbicide; $\mathrm{S}=$ sensitive response to herbicide.

Table 4. Correlation of percentage of $\mathrm{F}_{4}$ plants per $\mathrm{F}_{3}$ family sensitive to nicosulfuron, mesotrione, and dicamba + diflufenzopyr and carfentrazone injury ratings when $143 \mathrm{~F}_{3: 4}$ families derived from crosses of sweet corn inbreds $\mathrm{Cr} 1$ and $\mathrm{Cr} 2$ were screened in greenhouse trials.

\begin{tabular}{lccc}
\hline & \multicolumn{3}{c}{ Herbicide treatments (correlation coefficient) } \\
\cline { 2 - 4 } $\begin{array}{l}\text { Herbicide } \\
\text { treatments }\end{array}$ & Mesotrione & $\begin{array}{c}\text { Dicamba }+ \\
\text { diflufenzopyr }\end{array}$ & Carfentrazone \\
\hline Nicosulfuron & 0.93 & 0.84 & 0.78 \\
Mesotrione & --- & 0.84 & 0.76 \\
Dicamba + diflufenzopyr & --- & --- & 0.73 \\
\hline
\end{tabular}

FieLd TRIALS. Segregation of progeny in the $\mathrm{F}_{2}, \mathrm{BC}_{1}, \mathrm{BC}_{1} \mathrm{~S}_{1}$, and $\mathrm{BC}_{2} \mathrm{~S}_{1}$ and segregation of $\mathrm{BC}_{1}, \mathrm{BC}_{2}$, and $\mathrm{F}_{2}$ family responses were not different from the ratios expected if tolerance to each of the herbicide treatments (except for bentazon) was conditioned by a single, dominant gene. All plants of $\mathrm{Cr} 1$ were sensitive to nicosulfuron, mesotrione, dicamba + diflufenzopyr, foramsulfuron, bentazon, primisulfuron, and rimsulfuron (Tables 5-6). Injury due to carfentrazone on $\mathrm{Cr} 1$ was rated 7.5 (Table 6). All plants of $\mathrm{Cr} 2$ and $94 \%$ or more of the plants in the $\mathrm{F}_{1}$ and $\mathrm{BC}_{2}$ generations were tolerant to nicosulfuron, mesotrione, dicamba + diflufenzopyr, foramsulfuron, bentazon, primisulfuron, and rimsulfuron (Tables 5-6). A few plants in each generation had very mild symptoms of injury from mesotrione and dicamba+diflufenzopyr that were classified as tolerant, similar to the greenhouse trials. Injury due to carfentrazone was rated 5.3, 4.5, and 4.8 for $\mathrm{Cr} 2$ and the $\mathrm{F}_{1}$ and $\mathrm{BC}_{2}$ generations, respectively (Table 6).

Based on chi-square goodness-of-fit tests, ratios of tolerant and sensitive progeny in the $\mathrm{F}_{2}, \mathrm{BC}_{1}, \mathrm{BC}_{1} \mathrm{~S}_{1}$, and $\mathrm{BC}_{2} \mathrm{~S}_{1}$ generations were not significantly different $(P>0.01)$ from $3: 1,1: 1,3: 5$, and 7:1, respectively, for nicosulfuron, mesotrione, dicamba + 
Table 5. Segregation analysis for responses to nicosulfuron, mesotrione, dicamba + diflufenzopyr, foramsulfuron, and bentazon when sweet corn inbreds $\mathrm{Cr} 1$ and $\mathrm{Cr} 2$ and their progeny were screened in field trials.

\begin{tabular}{|c|c|c|c|c|c|c|c|c|c|c|c|c|c|c|c|c|c|c|c|c|c|c|}
\hline \multirow[b]{3}{*}{ Generation } & \multirow{2}{*}{\multicolumn{2}{|c|}{$\begin{array}{l}\text { Expected } \\
\text { ratios }^{z}\end{array}$}} & \multicolumn{20}{|c|}{ Segregation for tolerant $(\mathrm{T})$ and sensitive $(\mathrm{S})$ plants following herbicide treatments (no. progeny) } \\
\hline & & & \multicolumn{4}{|c|}{ Nicosulfuron } & \multicolumn{4}{|c|}{ Mesotrione } & \multicolumn{4}{|c|}{$\begin{array}{c}\text { Dicamba+ } \\
\text { diflufenzopyr }\end{array}$} & \multicolumn{4}{|c|}{ Foramsulfuron } & \multicolumn{4}{|c|}{ Bentazon } \\
\hline & $\mathrm{T}$ & $\mathrm{S}^{\mathrm{z}}$ & $\mathrm{T}$ & $\mathrm{S}$ & $\chi^{2}$ & $P$ & $\mathrm{~T}$ & $\mathrm{~S}$ & $\chi^{2}$ & $P$ & $\mathrm{~T}$ & $\mathrm{~S}$ & $\chi^{2}$ & $P$ & $\mathrm{~T}$ & $\mathrm{~S}$ & $\chi^{2}$ & $P$ & $\mathrm{~T}$ & $\mathrm{~S}$ & $\chi^{2}$ & $P$ \\
\hline$\overline{\mathrm{Cr} 1}$ & 0 & 1 & 0 & 40 & & & 0 & 42 & & & 0 & 31 & & & 0 & 36 & & & 0 & 37 & & \\
\hline $\mathrm{Cr} 2$ & 1 & 0 & 46 & 0 & & & 42 & 0 & & & 34 & 0 & & & 45 & 0 & & & 47 & 0 & & \\
\hline$F_{1}$ & 1 & 0 & 44 & 0 & & & 43 & 3 & & & 35 & 1 & & & 40 & 0 & & & 45 & 0 & & \\
\hline $\mathrm{F}_{2}$ & 3 & 1 & 103 & 22 & 3.65 & 0.06 & 105 & 28 & 1.11 & 0.29 & 86 & 32 & 0.28 & 0.60 & 91 & 31 & 0.01 & 0.92 & 109 & 17 & 8.9 & 0.003 \\
\hline $\mathrm{BC}_{1}$ & 1 & 1 & 58 & 46 & 1.39 & 0.24 & 50 & 51 & 0.01 & 0.92 & 60 & 54 & 0.32 & 0.57 & 58 & 61 & 0.07 & 0.78 & 61 & 40 & 4.37 & 0.04 \\
\hline $\mathrm{BC}_{2}$ & 1 & 0 & 111 & 5 & & & 114 & 4 & & & 110 & 6 & & & 122 & 3 & & & 102 & 1 & & \\
\hline $\mathrm{F}_{3}$ & 5 & 3 & 558 & 554 & 72.0 & $<0.001$ & 539 & 502 & 51.1 & $<0.001$ & 549 & 532 & 63.3 & $<0.001$ & 522 & 476 & 44.3 & $<0.001$ & 683 & 290 & 24.6 & $<0.001$ \\
\hline $\mathrm{BC}_{1} \mathrm{~S}_{1}$ & 3 & 5 & 348 & 498 & 4.77 & 0.03 & 344 & 534 & 1.06 & 0.30 & 349 & 516 & 2.99 & 0.08 & 326 & 528 & 0.17 & 0.68 & 461 & 349 & 130.3 & $<0.001$ \\
\hline $\mathrm{BC}_{2} \mathrm{~S}_{1}$ & 7 & 1 & 919 & 116 & 1.58 & 0.21 & 942 & 149 & 1.34 & 0.25 & 987 & 140 & 0.01 & 0.94 & 995 & 123 & 2.29 & 0.13 & 1040 & 30 & 91.9 & $<0.001$ \\
\hline
\end{tabular}

${ }^{2}$ Expected ratios of tolerant and sensitive plants if tolerance is conditioned by a single, dominant gene.

Table 6. Segregation analysis for responses to primisulfuron and rimsulfuron and carfentrazone injury rating when sweet corn inbreds Cr1 and $\mathrm{Cr} 2$ and their progeny were screened in field trials.

\begin{tabular}{|c|c|c|c|c|c|c|c|c|c|c|c|}
\hline \multirow[b]{3}{*}{ Generation } & & & \multicolumn{8}{|c|}{$\begin{array}{l}\text { Segregation for tolerant }(\mathrm{T}) \text { and sensitive }(\mathrm{S}) \text { plants } \\
\text { following herbicide treatments (no. progeny) }\end{array}$} & \multirow{3}{*}{$\begin{array}{l}\text { Carfentrazone } \\
\text { injury }(1-9)\end{array}$} \\
\hline & \multicolumn{2}{|c|}{ Expected ratios ${ }^{\mathrm{z}}$} & \multicolumn{4}{|c|}{ Primisulfuron } & \multicolumn{4}{|c|}{ Rimsulfuron } & \\
\hline & $\mathrm{T}$ & $\mathrm{S}$ & $\mathrm{T}$ & $\mathrm{S}$ & $\chi^{2}$ & $P$ & $\mathrm{~T}$ & $\mathrm{~S}$ & $\chi^{2}$ & $P$ & \\
\hline$\overline{\mathrm{Cr} 1}$ & 0 & 1 & 0 & 79 & & & 0 & 73 & & & 7.5 \\
\hline $\mathrm{Cr} 2$ & 1 & 0 & 76 & 0 & & & 86 & 0 & & & 5.3 \\
\hline $\mathrm{F}_{1}$ & 1 & 0 & 90 & 0 & & & 96 & 0 & & & 4.5 \\
\hline $\mathrm{F}_{2}$ & 3 & 1 & 293 & 93 & 0.17 & 0.08 & 300 & 87 & 1.31 & 0.25 & 5.5 \\
\hline $\mathrm{BC}_{1}$ & 1 & 1 & 151 & 147 & 0.54 & 0.82 & 138 & 158 & 1.35 & 0.25 & 6.0 \\
\hline $\mathrm{BC}_{2}$ & 1 & 0 & 167 & 0 & & & 158 & 0 & & & 4.8 \\
\hline
\end{tabular}

${ }^{2}$ Expected ratios of tolerant and sensitive plants if tolerance is conditioned by a single, dominant gene.

Table 7. Segregation analysis for response to nicosulfuron, mesotrione, dicamba + diflufenzopyr, carfentrazone, foramsulfuron, and bentazon when $\mathrm{BC}_{1} \mathrm{~S}_{1}, \mathrm{BC}_{2} \mathrm{~S}_{1}$, and $\mathrm{F}_{2}$ families derived from crosses of sweet corn inbreds $\mathrm{Cr} 1$ and $\mathrm{Cr} 2$ were screened in field trials.

\begin{tabular}{|c|c|c|c|c|c|c|c|c|c|c|c|c|c|c|c|}
\hline \multirow[b]{2}{*}{ Herbicide treatment } & \multicolumn{5}{|c|}{$\begin{array}{l}\text { Segregation of } \mathrm{BC}_{1} \text { families } \\
\text { (no. families) }\end{array}$} & \multicolumn{5}{|c|}{$\begin{array}{c}\text { Segregation of } \mathrm{BC}_{2} \text { families } \\
\text { (no. families) }\end{array}$} & \multicolumn{5}{|c|}{$\begin{array}{l}\text { Segregation of } \mathrm{F}_{2} \text { families } \\
\text { (no. families) }\end{array}$} \\
\hline & $\mathrm{Ty}$ & Seg. ${ }^{y}$ & $\mathrm{~S}_{\mathrm{y}}$ & $\chi^{2}$ & $P$ & $\mathrm{~T}$ & Seg. & $\mathrm{S}$ & $\chi^{2}$ & $P$ & $\mathrm{~T}$ & Seg. & $\mathrm{S}$ & $\chi^{2}$ & $P$ \\
\hline Nicosulfuron & 0 & 17 & 11 & 1.3 & 0.26 & 14 & 14 & 0 & 0 & 1 & 8 & 6 & 14 & 11.7 & 0.003 \\
\hline Mesotrione & 0 & 17 & 11 & 1.3 & 0.26 & 15 & 13 & 0 & 0.14 & 0.71 & 9 & 8 & 12 & 6.4 & 0.04 \\
\hline Dicamba + diflufenzopyr & 0 & 17 & 11 & 1.3 & 0.26 & 15 & 13 & 0 & 0.14 & 0.71 & 9 & 8 & 12 & 6.4 & 0.04 \\
\hline Carfentrazone & 4 & 14 & 9 & $3.0^{\mathrm{x}}$ & 0.08 & 11 & 13 & 4 & $1.3^{\mathrm{w}}$ & 0.26 & 9 & 8 & 12 & 6.4 & 0.04 \\
\hline Foramsulfuron & 0 & 17 & 11 & 1.3 & 0.26 & 15 & 13 & 0 & 0.14 & 0.71 & 9 & 7 & 12 & 7.6 & 0.02 \\
\hline Bentazon & 1 & 22 & 5 & $11.6^{y}$ & $<0.001$ & 21 & 7 & 0 & 7.0 & 0.01 & 15 & 7 & 6 & 12.8 & 0.002 \\
\hline
\end{tabular}

$\overline{{ }^{2} \text { Expected ratios of tolerant, segregating, and sensitive families if tolerance is conditioned by a single, dominant gene: } \mathrm{BC} 1 \text { families }(0: 1: 1), \mathrm{BC}_{2}}$ families (1:1:0), and $\mathrm{F}_{2}$ families $(1: 2: 1)$.

y $\mathrm{T}=$ tolerant; Seg. = segregating; $\mathrm{S}=$ sensitive.

xTolerant and segregating families combined for chi-square test of goodness-of-fit.

wSensitive and segregating families combined for chi-square test of goodness-of-fit.

diflufenzopyr, and foramsulfuron (Table 5). Similarly, ratios of tolerant and sensitive progeny in the $\mathrm{F}_{2}$ and $\mathrm{BC}_{1}$ generations were not significantly different $(P>0.01)$ from $3: 1$ and $1: 1$, respectively, for primisulfuron and rimsulfuron (Table 6). There were no differences between reciprocal $\mathrm{BC}_{1}$ generations. Carfentrazone injury ratings were 5.5 and 6.0 for the $\mathrm{F}_{2}$ and $\mathrm{BC}_{1}$ generations, respectively (Table 5). Segregation of progeny tolerant or sensitive to bentazon in the $\mathrm{F}_{2}, \mathrm{BC}_{1} \mathrm{~S}_{1}, \mathrm{BC}_{2} \mathrm{~S}_{1}$, and $\mathrm{F}_{3}$ generations did not fit the ratios expected for a single gene. Likewise, ratios of progeny tolerant or sensitive to each of the herbicide treatments in the $\mathrm{F}_{3}$ generation did not fit the ratios hypothesized for a single gene due to higher than expected numbers of sensitive plants
(Table 5). The number of sensitive $\mathrm{F}_{3}$ plants was influenced by ratios of sensitive, segregating, and tolerant $\mathrm{F}_{2}$ families (Table 7). While those ratios fit the ratios expected for a single gene (see below), there were more sensitive than tolerant $\mathrm{F}_{2}$ families, thus influencing ratios of $\mathrm{F}_{3}$ plants.

Based on chi-square goodness-of-fit tests, ratios of tolerant, segregating, and sensitive $\mathrm{BC}_{1}, \mathrm{BC}_{2}$, and $\mathrm{F}_{2}$ family responses to nicosulfuron, mesotrione, dicamba + diflufenzopyr, carfentrazone, and foramsulfuron were not significantly different $(P \leq 0.01)$ from those expected if tolerance was conditioned by a single, dominant gene except for the response of $\mathrm{F}_{2}$ families to nicosulfuron ( $P$ $=0.003)($ Table 7$)$. However, for each of these herbicide treat- 
Table 8. Segregation analysis for responses of plants and families to bentazon when sweet corn inbreds Cr1 and $\mathrm{Cr} 2$ and their progeny were screened in field trials.

\begin{tabular}{|c|c|c|c|c|c|c|c|c|}
\hline & \multicolumn{3}{|c|}{ Expected ratios ${ }^{2}$} & \multicolumn{5}{|c|}{$\begin{array}{l}\text { Tolerant, segregating or sensitive plants } \\
\text { or families (no. of plants or families) }\end{array}$} \\
\hline & $\mathrm{Ty}$ & Seg. ${ }^{x}$ & $\mathrm{~S}^{\mathrm{w}}$ & $\mathrm{T}$ & Seg. & $\mathrm{S}$ & $\chi^{2}$ & $P$ \\
\hline \multicolumn{9}{|c|}{ Generations } \\
\hline $\mathrm{F}_{2}$ & 15 & & 1 & 109 & & 17 & 11.3 & $<0.001$ \\
\hline $\mathrm{BC}_{1}$ & 3 & & 1 & 61 & & 40 & 11.5 & $<0.001$ \\
\hline $\mathrm{F}_{3}$ & 55 & & 9 & 1040 & & 30 & 112 & $<0.001$ \\
\hline $\mathrm{BC}_{1} \mathrm{~S}_{1}$ & 39 & & 25 & 683 & & 290 & 35 & $<0.001$ \\
\hline $\mathrm{BC}_{2} \mathrm{~S}_{1}$ & 15 & & 1 & 461 & & 349 & 1876 & $<0.001$ \\
\hline \multicolumn{9}{|l|}{ Families } \\
\hline $\mathrm{BC}_{1}$ & 0 & 3 & 1 & 1 & 22 & 5 & $0.76^{y}$ & 0.38 \\
\hline $\mathrm{BC}_{2}$ & 3 & 1 & 0 & 21 & 7 & 0 & 1 & 1.0 \\
\hline $\mathrm{F}_{2}$ & 7 & $8^{z}$ & 1 & 15 & 7 & 6 & 14.4 & $<0.001$ \\
\hline
\end{tabular}

${ }^{\mathrm{z}}$ Expected ratios if response to bentazon is conditioned by two independent, dominant genes.

y $\mathrm{T}=$ tolerant; Seg. = segregating; $\mathrm{S}=$ sensitive.

xTolerant and segregating families combined for chi-square test of goodness-of-fit.

wIncludes four families each that are expected to segregate 15:1 and 3:1.

Table 9. Correlation of percentage of plants sensitive to nicosulfuron, mesotrione, dicamba + diflufenzopyr, foramsulfuron, and bentazon and carfentrazone injury ratings when $28 \mathrm{BC}_{1} \mathrm{~S}_{1}, 28 \mathrm{BC}_{2} \mathrm{~S}_{1}$, and $30 \mathrm{~F}_{2}$ families derived from crosses of sweet corn inbreds $\mathrm{Cr} 1$ and $\mathrm{Cr} 2$ were screened in field trials.

\begin{tabular}{lccccc}
\hline & \multicolumn{5}{c}{ Herbicide treatments (correlation coefficient) } \\
\cline { 2 - 6 } $\begin{array}{l}\text { Herbicide } \\
\text { treatments }\end{array}$ & Mesotrione & $\begin{array}{c}\text { Dicamba }+ \\
\text { diflufenzopyr }\end{array}$ & Carfentrazone & Foramsulfuron & Bentazon \\
\hline Nicosulfuron & 0.96 & 0.94 & 0.77 & 0.97 & 0.71 \\
Mesotrione & --- & 0.95 & 0.77 & 0.98 & 0.72 \\
Dicamba+ diflufenzopyr & --- & --- & 0.82 & 0.95 & 0.77 \\
Carfentrazone & --- & --- & --- & 0.78 & 0.66 \\
Foramsulfuron & --- & --- & --- & 0.73 \\
\hline
\end{tabular}

ments, probabilities associated with the chi-square tests of $\mathrm{F}_{2}$ family responses were relatively low (i.e., probabilities ranging from 0.07 to 0.02 ) as a result of larger than expected number of sensitive families (Table 7). For bentazon, responses of $\mathrm{BC}_{1}, \mathrm{BC}_{2}$, and $\mathrm{F}_{2}$ families failed to fit the expected ratios due to a greater than expected number of tolerant responses among $\mathrm{BC}_{2}$ and $\mathrm{F}_{2}$ families and a greater than expected number of segregating responses among $\mathrm{BC}_{1}$ families (Table 7).

Segregation of responses to bentazon also was tested by chisquare goodness-of-fit for ratios expected if two independent genes conditioned tolerance. Segregation of plants within generations did not fit a two-gene model (Table 8). Segregation of responses of $\mathrm{BC}_{1}$ and $\mathrm{BC}_{2}$ families fit a two-gene model, but segregation of responses of $\mathrm{F}_{2}$ families did not (Table 8).

Correlations among the percentage of plants in $28 \mathrm{BC}_{1}, 28$ $\mathrm{BC}_{2}$, and $30 \mathrm{~F}_{2}$ families that were sensitive to nicosulfuron, mesotrione, dicamba + diflufenzopyr, and foramsulfuron ranged from 0.95 to 0.98 (Table 9). Correlations among the responses of families to these four herbicide treatments and carfentrazone injury ratings ranged from 0.77 to 0.82 . Correlations among percentage of plants in $28 \mathrm{BC}_{1}, 28 \mathrm{BC}_{2}$, and $30 \mathrm{~F}_{2}$ families that were sensitive to bentazon and responses to the other five herbicide treatments ranged from 0.66 to 0.77 . Families tolerant to the other five herbicide treatments were tolerant to bentazon. However, families that segregated for response to the other five herbicide treatments were tolerant or segregating for response to bentazon; and families that were sensitive to the other five herbicide treatments were sensitive, tolerant, or segregating for response to bentazon.

\section{Discussion}

An association between the responses of sweet corn hybrids and inbreds to nicosulfuron and mesotrione and segregation for response to nicosulfuron and mesotrione in $\mathrm{F}_{2}$ families derived from a cross of $\mathrm{Cr} 1$, a sensitive inbred, and $\mathrm{Cr} 2$, a tolerant inbred (Williams et al., 2005), prompted us to examine the inheritance of sensitivity to multiple postemergence herbicides in sweet corn. Based on segregation of tolerant and sensitive progeny and segregation of family responses, our data indicate that a single recessive gene in sweet corn inbred $\mathrm{Cr} 1$ conditions sensitivity to four ALSinhibiting herbicides (foramsulfuron, nicosulfuron, primisulfuron, and rimsulfuron), an HPPD-inhibiting herbicide (mesotrione), a growth regulator herbicide combination (dicamba + diflufenzopyr), and a PPO-inhibiting herbicide (carfentrazone). Based on highly significant positive correlations of phenotypic responses among $\mathrm{F}_{3: 4}, \mathrm{BC}_{1} \mathrm{~S}_{1}, \mathrm{BC}_{2} \mathrm{~S}_{1}$, and $\mathrm{F}_{2}$ families, the same gene (or closely linked genes) appears to condition responses to each of these herbicide treatments. This gene also appears to affect the response to bentazon since families that were tolerant to the other herbicide treatments were tolerant to bentazon. However, other gene(s) may be involved in tolerance to bentazon since families sensitive to the other herbicide treatments were tolerant, segregating, or sensitive for response to bentazon, and families segregating for response to the other herbicide treatments were tolerant or segregating for response to bentazon. Previously, Bradshaw et al. (1994) proposed that sensitivity of GA209 to bentazon was controlled by two recessive genes which Barrett et al. (1997) proposed were linked. 
Our results corroborate and expand on previous studies of the genetic basis of herbicide sensitivity in corn. In addition to observing simply inherited sensitivity to multiple ALS-inhibiting herbicides and slightly more complex inheritance of tolerance to bentazon, we propose that a single gene in $\mathrm{Cr} 1$ also conditions sensitivity to an HPPD-inhibiting herbicide, a PPO-inhibiting herbicide, and a growth regulator herbicide. Previous researchers demonstrated that response of corn to several ALS-inhibiting herbicides was inherited as a single recessive gene (Green and Ulrich, 1993; Harms et al., 1990; Kang, 1993; Widstrom and Dowler, 1995). Kang (1993) designated the gene responsible for sensitivity to nicosulfuron as $n s f 1$, which subsequently was mapped to the short arm of chromosome 7 using maize B-A translocation stocks (Moreno et al., 1999). Green (1998) cited unpublished data for the inbred $\mathrm{F}_{2}$ that mapped sensitivity to rimsulfuron to the short arm of chromosome 5. Williams et al. (2006) recently used a map-based cloning approach to identify the position and sequence of the nsfl gene on the short arm of chromosome 5. Sensitivity of GA209 to bentazon was inherited as a single gene or two genes that may be linked, which were designated as ben1 and ben2 (Bradshaw et al., 1994; Fleming et al., 1988). GA209 was also more sensitive to imazethapyr, nicosulfuron, primisulfuron, and chlortoluron and slightly more sensitive to dicamba than B73, a bentazon-tolerant inbred (Barrett et al., 1997). These authors proposed that the benl gene was associated with metabolism of bentazon and nicosulfuron while the ben 2 gene was associated only with metabolism of bentazon. The gene that conditions sensitivity of $\mathrm{Cr} 1$ to multiple herbicides may be allelic with the benl and/or $n s f l$ genes. The pleiotrophic responses to multiple herbicides may be due to regulation of a major cytochrome P450 enzyme, which Barrett et al. (1994) labeled as a "super P450." Based on a recent cloning study (Williams et al., 2006), the $n s f 1$ gene appears to be a P450. Alternatively, the gene in Cr1 may be different from the ben 1 and/or nsfl gene(s) and may affect the regulation of multiple cytochrome P450s or other enzymes involved in herbicide metabolism. It is possible that metabolism of herbicides in corn may involve more than one cytochrome P450. Cross-tolerance to various herbicides with different chemical structures and different modes of action was recently observed in transgenic rice plants that expressed three different human P450 genes, CYP1A1, CYP2B6, and CYP2C19 (Hirose et al., 2005; Kawahigashi et al., 2005).

In our trials, responses to the ALS-inhibiting herbicides and to bentazon were unambiguous. Plants had no symptoms of injury or they were mostly necrotic following applications of bentazon or ALS-inhibiting herbicides. Conversely, responses to mesotrione and dicamba + diflufenzopyr sometimes were intermediate. Leaves of intermediate phenotypes were slightly bleached by mesotrione, and plants with intermediate responses to dicamba + diflufenzopyr had slight abnormalities in growth that were more similar to tolerant phenotypes than sensitive phenotypes. Intermediate responses were not consistently discernable enough to separate as a different phenotypic class; however, we hypothesize that an intermediate phenotypic class would be observed if more precise methods could be used to measure responses to these herbicide treatments. In other words, we propose that herbicide metabolism in plants heterozygous for the primary gene affecting herbicide response in progeny of $\mathrm{Cr} 1 \times \mathrm{Cr} 2$ may be intermediate to that of plants that are homozygous tolerant or homozygous sensitive. Thus, under some environmental conditions or at certain application rates of these herbicides, phenotypes may segregate as a co-dominant trait rather than as the dominant trait observed in these experiments.
Sweet corn hybrids are frequently evaluated for responses to herbicides in multiple years and locations due to responses that are not always consistent across environments. Inconsistent responses across environments may occur if plants have an intermediate rate of herbicide metabolism. If the gene in $\mathrm{Cr} 1$ that conditions sensitivity to multiple herbicides acts in a co-dominant manner, and certain sweet corn hybrids are heterozygous for this gene (or similar genes), those hybrids could respond differently among trials to herbicides affected by this gene. Based on segregation of tolerant and sensitive progeny in $\mathrm{F}_{2}$ generations, over 35 sweet corn hybrids were recently identified to be heterozygous for a gene(s) affecting sensitivity to nicosulfuron and mesotrione (J.K. Pataky and M.M. Williams, unpublished). Additional research is necessary to determine if these hybrids and their inbreds are allelic for the gene that conditions herbicide sensitivity in $\mathrm{Cr} 1$ and if heterozygotes have an intermediate rate of metabolism that results in herbicide injury under certain conditions. Similarly, additional tests are necessary to determine if the gene that conditions herbicide sensitivity in $\mathrm{Cr} 1$ is the same as the ben 1 and/or $n s f 1$ gene(s). Evaluation of responses of progeny of $\mathrm{Cr} 1 \times \mathrm{Cr} 2$ to additional herbicides also would be useful in determining the spectrum of cross-sensitivity conferred by the gene in $\mathrm{Cr} 1$.

\section{Literature Cited}

Barrett, M. 1995. Metabolism of herbicides by cytochrome P450. Drug Metabolism Drug Interactions 12:299-315.

Barrett, M. 2000. The role of cytochrome P450 enzymes in herbicide metabolism, p. 25-37. In: A.H. Cobb and R.C. Kirkwood (eds.). Herbicides and their mechanisms of action. CRC Press, Boca Raton, Fla.

Barrett, M., L.D. Bradshaw, N.D. Polge, R.J. Baerg, and C.G. Poneleit. 1994. Evidence for multiple herbicide metabolizing cytochrome P450 from maize. Weed Sci. Soc. Amer. Abstr. 34:60. (Abstr.).

Barrett, M., N. Polge, R. Baerg, R. Bradshaw, and C. Poneleit. 1997. Role of cytochrome P450 in herbicide metabolism and selectivity and multiple herbicide metabolizing cytochrome P450 activities in maize, p. 35-50. In: K. Hatzios (ed.). Regulation of enzymatic systems detoxifying xenobiotics in plants. Kluwer Academic Publ., Dordrecht, The Netherlands.

Boldt, L.D., M. Barrett, C.G. Poneleit, and N.D. Polge. 1992. Cytochrome P450 monooxygenase activity and cross-sensitivity to other herbicides of a bentazon-susceptible corn inbred. Weed Sci. Soc. Amer. Abstr. 32:185. (Abstr.).

Bradshaw, L.D., M. Barrett, and C.G. Poneleit. 1994. Inheritance of bentazon susceptibility in a corn (Zea mays) line. Weed Sci. 42:641-647.

Burton, J.D., E.P. Maness, D.W. Monks, and R.R. Robinson. 1994. Sulfonylurea selectivity and safener activity in 'Landmark' and 'Merit' sweet corn. Pesticide Biochem. Physiol. 48:163-172.

Diebold, S., D. Robinson, J. Zandstra, J. O'Sullivan, and P.H. Sikkema. 2003. Sweet corn (Zea mays) cultivar sensitivity to AE F130360. Weed Technol. 17:127-132.

Diebold, S., D. Robinson, J. Zandstra, J. O'Sullivan, and P.H. Sikkema. 2004. Sweet corn sensitivity to bentazon. Weed Technol. 18:982-987.

Fleming, A.A., P.A. Banks, and J.G. Legg. 1988. Differential responses of maize inbreds to bentazon and other herbicides. Can. J. Plant Sci. 68:501-507.

Fonné-Pfister, R., J. Gaudin, K. Kreuz, K. Ramsteiner, and E. Ebert. 1990. Hydroxylation of primisulfuron by an inducible cytochrome P450-dependent monooxygenase system from maize. Pesticide Biochem. Physiol. 37:165-173.

Frey, M., R. Kliem, H. Saedler, and A. Gierl. 1995. Expression of a cytochrome P450 gene family in maize. Mol. Gen. Genet. 246:100-109.

Green,J.M. 1998. Differential tolerance of corn(Zea mays) inbreds to four sulfonlyurea herbicides and bentazon. Weed Technol. 12:474-477. 
Green, J.M. and J.F. Ulrich. 1993. Response of corn (Zea mays L.) inbreds and hybrids to sulfonylurea herbicides. Weed Sci. 41:508-516.

Grey, T.L., D.C. Bridges, P. Raymer, D. Day, and D.S. NeSmith. 2000. Differential tolerance of fresh market sweet corn cultivars to the herbicides nicosulfuron and primisulfuron. HortScience 35:1070-1073.

Harms, C.T., A.L. Montoya, L.S. Privalle, and R.W. Briggs. 1990. Genetic and biochemical characterization of corn inbred lines tolerant to the sulfonylurea herbicide primisulfuron. Theor. Appl. Genet. 80:353-358.

Hinz, J.R.R. and M.D.K. Owen. 1996. Nicosulfuron and primisulfuron selectivity in corn (Zea mays) and two annual grass weeds. Weed Sci. 44:219-223.

Hirose, S., H. Kawahigashi, K. Ozawa, N. Shiota, H. Inui, H. Ohkawa, and Y. Ohkawa. 2005. Transgenic rice containing human $C Y P 2 B 2$ detoxifies various classes of herbicides. J Agr. Food Chem. 53:3461-3467.

Kang, M.S. 1993. Inheritance of susceptibility to nicosulfuron herbicide in maize. J. Hered. 84:216-217.

Kawahigashi, H., S. Hirose, H. Inui, H. Ohkawa, and Y. Ohkawa. 2005. Enhanced herbicide cross-tolerance in transgenic rice plants co-expressing human $C Y P 1 A 1, C Y P 2 B 6$, and $C Y P 2 C 19$. Plant Sci. 168:773-781.

Kreuz, K., R. Tommasini, and E. Martinoia. 1996. Old enzymes for a new job: Herbicide detoxification in plants. Plant Physiol. 111:349-353.

Landi, P., A. Vicari, and P. Catizone. 1989. Response of maize (Zea mays L.) inbred lines and hybrids to chlorsulfuron. Weed Res. 29:265-271.

Masiunas, J., J. Pataky, C. Sprague, M. Williams, and L. Wax. 2004. Sweet corn cultivar tolerance to mesotrione. Weed Sci. Soc. Amer. Abstr. 44:58. (Abstr.).

Monks, D.W., C.A. Mullins, and K.E. Johnson. 1992. Response of sweet corn (Zea mays) to nicosulfuron and primisulfuron. Weed Technol. 6:280-283.

Moreno, O.J., M.S. Kang, G. Wang, and N. Aminha. 1999. Chromosomal location of $n f s 1$ gene in maize by use of B-A translocations. Amer. Soc. Agron. Abstr. 91:75. (Abstr.).
Morton, C.A. and R.G. Harvey. 1992. Sweet corn (Zea mays) hybrid tolerance to nicosulfuron. Weed Technol. 6:91-96.

O'Sullivan, J. and W.J. Bouw. 1998. Sensitivity of processing sweet corn (Zea mays) cultivars to nicosulfuron/rimsulfuron. Can. J. Plant Sci. 78:151-154.

O'Sullivan, J., R.A. Brammall, and W.J. Bouw. 1995. Response of sweet corn (Zea mays) cultivars to nicosulfuron plus rimsulfuron. Weed Technol. 9:58-62.

O'Sullivan, J. and P.H. Sikkema. 2002. Sweet corn (Zea mays) cultivar tolerance to primisulfuron. Can. J. Plant Sci.82:261-264.

O’Sullivan, J., P.H. Sikkema, and R.J. Thomas. 2000. Sweet corn (Zea mays) cultivar tolerance to nicosulfuron. Can. J. Plant Sci. 80:419-423.

O’Sullivan, J., J. Zandstra, and P. Sikkema. 2002. Sweet corn (Zea mays) cultivar sensitivity to mesotrione. Weed Technol.16:421-425.

Ritchie, S.W., J.J. Hanway, G.O. Benson, and J.C. Herman. 2003. How a corn plant develops. Iowa State Univ. of Sci. and Technol. Coop. Ext. Serv., Spec. Rpt. No. 48 (revised).

Robinson, D.K., D.W. Monks, and J.R. Schultheis. 1994. Effect of nicosulfuron applied postemergence and post-directed on sweet corn (Zea mays) tolerance. Weed Technol. 8:630-634.

Robinson, D.K., D.W. Monks, J.R. Schultheis, and A.D. Worsham. 1993. Sweet corn (Zea mays) cultivar tolerance to application timing of nicosulfuron. Weed Technol. 7:840-843.

Stall, W.M. and T.A. Bewick. 1992. Sweet corn cultivars respond differently to the herbicide nicosulfuron. HortScience 27:131-133.

Widstrom, N.W. and C.C. Dowler. 1995. Sensitivity of selected field corn inbreds (Zea mays) to nicosulfuron. Weed Technol. 9:779-782.

Williams, M.M. II, J.K. Pataky, J.N. Nordby, D.E. Riechers, C.L. Sprague, and J.B. Masiunas. 2005. Cross-sensitivity in sweet corn to nicosulfuron and mesotrione applied postemergence. HortScience 40:1801-1805.

Williams, M., S. Sowinski, T. Dam, and B.L. Li. 2006. Map-based cloning of the $n s f 1$ gene of maize. Program and Abstr. 48th Maize Gen. Conf. p. 49. (Abstr.). 